\title{
Soybean hull as an alternative biosorbent to uptake a reactive textile dye from aqueous solutions
}

\author{
Cesar Vinicius Toniciolli Rigueto ${ }^{1}$, Samara Correia Harala ${ }^{2}$, \\ Marieli Rosseto ${ }^{1}$, Bruna Elisangela Pessini Ostwald ${ }^{3}$, Lillian Ávila Massuda ${ }^{3}$, \\ Mateus Torres Nazari ${ }^{4}$, Aline Dettmer ${ }^{1}$, Raquel Aparecida Loss ${ }^{2}$, \\ Claudineia Aparecida Queli Geraldi ${ }^{2}$
}

\footnotetext{
${ }^{1}$ University of Passo Fundo (UPF), Faculty of Agronomy and Veterinary Medicine, Postgraduate Program in Food Science and Technology, Rod. BR 285, Campus I, São José, CEP: 99052-900, Passo Fundo, RS, Brazil

${ }^{2}$ Mato Grosso State University (UNEMAT), Faculty of Architecture and Engineering (FAE), Food Engineering Department, Street A, s/n, São Raimundo, CEP: 78390-000, Barra do Bugres, MT, Brazil

${ }^{3}$ University of Passo Fundo (UPF), Faculty of Engineering and Architecture (FEAR), Chemical Engineering Department, Rod. BR 285, Campus I, São José, CEP: 99052-900, Passo Fundo, RS, Brazil

${ }^{4}$ University of Passo Fundo (UPF), Faculty of Engineering and Architecture (FEAR), Postgraduate Program in Civil and Environmental Engineering (PPGEng), Rod. BR 285, Campus I, São José, CEP: 99052-900, Passo Fundo, RS, Brazil e-mail: cesartoniciolli@gmail.com
}

\begin{abstract}
The textile industries are responsible for generating large volumes of effluents containing toxic dyes, harmful to ecosystems if disposed of without prior treatment. The adsorption process stands out due to its simplicity and efficiency in removing a wide variety of contaminants present in effluents, also, it allows the use of residual biomass from agriculture. The soybean hull is a by-product of wide available but made used only for animal feed. Thus, the present study aimed to characterize and evaluate the soybean husk as a biosorbent of the $5 \mathrm{G}$ blue reactive dye, widely used in the dyeing processes of the textile industries. The soybean hull was characterized by SEM and FTIR. Kinetic and equilibrium tests were carried out under conditions of $\mathrm{pH} 2,40$ ${ }^{\circ} \mathrm{C}$, and $90 \mathrm{rpm}$. Besides, kinetic and equilibrium mathematical models previously described in the literature were adjusted to the experimental data. Through the morphological characterization of the biosorbent, it was possible to evidence superficial pores in practically all their extension, a characteristic that directly influences the adsorption process. The analysis of FTIR showed, as expected, the presence of functional groups characteristic of lignocellulosic substances. Besides, the results obtained in the kinetic and equilibrium essays in the studied conditions show that the adsorption equilibrium was obtained in about $120 \mathrm{~min}$, with the removal of $88 \%$ of the dye. The mathematical modeling indicated that the pseudo-second order and Sips models were the most adequate to represent the kinetic and equilibrium experimental data, respectively. The maximum adsorption capacities calculated experimentally and predicted by the Sips model were 53.33 and $48.13 \mathrm{mg} \mathrm{g}^{-1}$, respectively. In general, the biosorbent studied was effective to remove the reactive dye.
\end{abstract}

Keywords: textile effluent; biosorption; agroindustrial waste.

\section{INTRODUCTION}

The dyeing process of textile industries is the major responsibility for the generation of liquid effluents, being chemically complex due to the variety of dyes used, which are classified into: dispersants, acids, bases, salts, detergents, moisturizers, oxidizers, and others [1]. If these effluents are not properly treated before disposal in rivers or lakes, contamination of water bodies will be imminent, causing the reduction of dissolved oxygen in the water, in addition to affecting aquatic ecosystems, as well as the death of aquatic animals [2, 3].

In this context, several technologies have been studied as a method for the treatment of textile effluents, such as ion exchange, coagulation, and coagulation-flocculation, however, present as limitations the large number of reagents used and the generation of post-treatment sludge. Besides, biological treatments such as activated sludge (based on algae and anaerobic-aerobic) require physical space, care with microorganisms, 
and their restrictions and relatively long process time [3].

Given the limitations of conventional techniques, adsorption has stood out in the effective removal of color, since there is no generation of sludge, no use of physical spaces or expensive reagents. The efficiency of the process, however, is directly related to the choice of an adsorbent with high selectivity, easy acquisition, and low cost [4]. Thus, soybean hull (Glycine max) is a viable by-product for use as an adsorbent [5].

According to EMBRAPA [6], Brazil's 2018/19 soybean production reached approximately 115 million tons, of which about $10 \%$ hulls. While the grains can be used in different processes, the hulls are treated as agricultural waste, being destined only as animal feed, due to the low protein content $(11 \%)$ high fiber content $(36 \%)[7,8]$. Aiming at a greater utilization of this agro-industrial waste, soybean hulls has been reported as a promising alternative for use as an adsorbent in the removal of textile dye [9] and heavy metals [5]. In this sense, this study aimed to evaluate the adsorption capacity of in natura soybean hull (Glycine max) to remove the $5 \mathrm{G}$ blue reactive dye, commonly used in textile dyeing.

\section{MATERIALS AND METHODS}

\subsection{Obtainment and Preparation of Biosorbent}

Soybean hulls were collected from a soybean processing industry located in Rondonópolis, Mato Grosso, Brazil. The hulls were dried in a forced-air oven (CienLab CE-220) at $60{ }^{\circ} \mathrm{C}$ for $24 \mathrm{~h}$. They were then ground in a hammer mill (SP-33) and packed in polyethylene bags.

\subsection{Preparation of $5 \mathrm{G}$ reactive blue dye solutions}

Initially, a $500 \mathrm{mg} \mathrm{L}^{-1}$ stock solution of $5 \mathrm{G}$ reactive blue dye with $98 \%$ purity was prepared to be used in the dilutions of the other concentrations studied. Besides, a $100 \mathrm{mg} \mathrm{L}^{-1}$ solution was used to determine the maximum absorption length in a UV/Vis spectrophotometer (Varian, Cary 50 Scan), which was obtained at 610 $\mathrm{nm}$. To obtain the calibration of the curve, dye solutions were prepared with concentrations from $0 \mathrm{mg} \mathrm{L}^{-1}$ to $50 \mathrm{mg} \mathrm{L}^{-1}$ with an interval of $5 \mathrm{mg} \mathrm{L}^{-1}$. The $\mathrm{pH}$ of the dye solutions was adjusted by adding solutions of 0.1 mol $\mathrm{L}^{-1} \mathrm{HCl}$ or $\mathrm{NaOH}$, when necessary. All chemical reagents used were of analytical standard.

\subsection{Biosorbent characterization}

The biosorbent was characterized by Electronic scanning microscopy (SEM) (Tescan Vega3 LMU, Czech Republic). The samples were fixed in stub using double-sided carbon tapes and metalized with high vacuum gold. The analyses were performed at $5 \mathrm{kV}$ voltage accelerations, with magnifications of 80 and 1600 times.

To identify the functional groups, present in the biosorbent, the infrared analysis with Fourier (FTIR) transform was used. The samples were submitted to spectroscopic determination in the infrared region (4504500nm) (Prestige 21, 210045, Japan) using the total attenuated reflectance technique (ATR). The samples were submitted to drying in a greenhouse of forced air circulation at $60^{\circ} \mathrm{C}$ for $24 \mathrm{~h}$, to perform the analysis.

\subsection{Adsorption kinetics and isotherms}

The isotherms and adsorption kinetics were conducted under the better preliminary conditions $(\mathrm{pH} \mathrm{2,90} \mathrm{rpm}$ and $40{ }^{\circ} \mathrm{C}$ ), according to suggested by RIGUETO et al. [9]. The kinetics were performed with $50 \mathrm{~mL}$ of 5G blue reactive dye solution at a concentration of $100 \mathrm{mg} \mathrm{L}^{-1}$ and $0.3 \mathrm{~g}$ of biosorbent in $125 \mathrm{~mL}$ conical flasks. The equilibrium isotherms were constructed using $50 \mathrm{~mL}$ blue reactive dye solution of $5 \mathrm{G}$ at a concentration of $250 \mathrm{mg} \mathrm{L}^{-1}$, varying the biosorbent mass from 0.02 to $0.60 \mathrm{~g}$.

At the end of the kinetic and equilibrium assays, the samples were submitted to the centrifugation process, followed by spectrophotometric reading (Bel, SP-2000), and the dye concentration was determined by Equation 1.

$$
q=\frac{V\left(C_{0}-C\right)}{m}
$$

Where, $\mathrm{q}$ the amount of dye adsorbed per gram of water bath root $\left(\mathrm{mg} \mathrm{g}^{-1}\right), \mathrm{C}_{0}$ and $\mathrm{C}$ dye concentration in the initial and final aqueous solution respectively $\left(\mathrm{mg} \mathrm{L}^{-1}\right), \mathrm{V}$ the volume of dye solution $(\mathrm{L})$, and $\mathrm{m}$ the mass of biosorbent $(\mathrm{g})$.

The equilibrium was defined when the concentration of the dye showed standard error between its measurements of less than $5 \%$ in 3 measurements at $1 \mathrm{~h}$ intervals. 


\subsection{Mathematical modeling}

The equilibrium kinetics and isotherms were analyzed according to the models shown in Table 1 . The pseudo-first order and pseudo-second order models were applied to represent the adsorption kinetics, according to Equations 2 and 3. The adsorption isotherms were evaluated by the Langmuir, Freundlich, Temkin, and Sips models, according to Equations 4 to 7 . The parameters of the models were calculated using the software Origin $®$ version 15 , by minimizing the objective function sum of the squares [10].

Table 1: Equations of kinetic and equilibrium models.

\begin{tabular}{|c|c|c|}
\hline MODEL & EQUATIONS & \\
\hline \multicolumn{3}{|l|}{ KINETIC MODELS } \\
\hline Pseudo-first order & $q(t)=q_{1}\left(1-e^{-k_{1} t}\right)$ & (2) \\
\hline Pseudo-second order & $q(t)=\frac{t}{\left(1 / k_{2} q_{2}{ }^{2}\right)+\left(t / q_{2}\right)}$ & (3) \\
\hline \multicolumn{3}{|l|}{ ISOTHERM MODELS } \\
\hline Langmuir & $q_{e}=\frac{q_{m} K_{L} C_{e q}}{1+K_{L} C_{e q}}$ & (4) \\
\hline Freundlich & $q_{e}=K_{F} C_{e}^{1 / n F}$ & (5) \\
\hline Temkin & $\mathrm{q}_{\mathrm{eq}}=\mathrm{B} \ln \left(\mathrm{K}_{\mathrm{T}} C_{e q}\right)$ & (6) \\
\hline Sips & $q_{e}=\frac{q_{m} K_{S} C_{e}^{m}}{1+K C_{e}^{m}}$ & (7) \\
\hline
\end{tabular}

Where: $\mathrm{k} 1\left(\mathrm{~min}^{-1}\right)$ rate constant of pseudo-first-order, $\mathrm{q}_{1}\left(\mathrm{mg} \mathrm{g}^{-1}\right)$ theoretical value of adsorption capacity, $\mathrm{k}_{2}$ $\left(\mathrm{g} \mathrm{mg}^{-1} \mathrm{~min}^{-1}\right)$ rate constant of pseudo-second-order, $\mathrm{q}_{2}\left(\mathrm{mg} \mathrm{g}^{-1}\right)$ theoretical value of adsorption capacity, $\mathrm{q}_{\mathrm{m}}$ $\left(\mathrm{mg} \mathrm{g}^{-1}\right)$ maximum adsorption capacity, $\mathrm{K}_{\mathrm{L}}\left(\mathrm{L} \mathrm{mg}^{-1}\right)$ Langmuir constant, $\mathrm{K}_{\mathrm{F}}\left(\mathrm{mg} \mathrm{g}^{-1}\right)\left(\mathrm{mg} \mathrm{L}^{-1}\right)^{-1 / n}$ Freundlich constant, $1 / \mathrm{n}(-)$ heterogeneity factor, $\mathrm{B}\left(\mathrm{kJ} \mathrm{mol}^{-1}\right)$ Temkin isotherm constant, $\mathrm{kT}$ Temkin constant $\left(\mathrm{L} \mathrm{mg}^{-1}\right)$, $\mathrm{q}_{\mathrm{m}}\left(\mathrm{mg} \mathrm{g}^{-1}\right)$ maximum adsorption capacity, $\mathrm{K}_{\mathrm{S}}\left(\mathrm{L} \mathrm{mg}^{-1}\right)^{-\mathrm{m}}$ Sips constant, and $\mathrm{m}(-)$ heterogeneity factor.

\section{RESULTS AND DISCUSSION}

\subsection{Biosorbent characterization}

Scanning electron microscopy has been a very important tool to characterize the surface morphology and physical properties of the adsorbent. It is used to analyze porosity, particle shape, and appropriate size distribution [11]. Soybean hull scanning electron micrographs are shown in Figure 1.

The considerable number of pores present in the soybean hull, as shown in Figure 1, indicates the great possibility of dyes getting trapped and adsorbed in these pores. Besides, the surface morphology is irregular and rough. Similar morphology was also found by ARAMI et al. [11] and WEI et al. [12], who studied the surface characteristics of soybean hulls for adsorption of direct and acid dyes and $\mathrm{Pb}$ (II), respectively. Based on this morphology, it is observed that the soybean hull presents an adequate morphological profile to retain dyes like $5 \mathrm{G}$ reactive. 


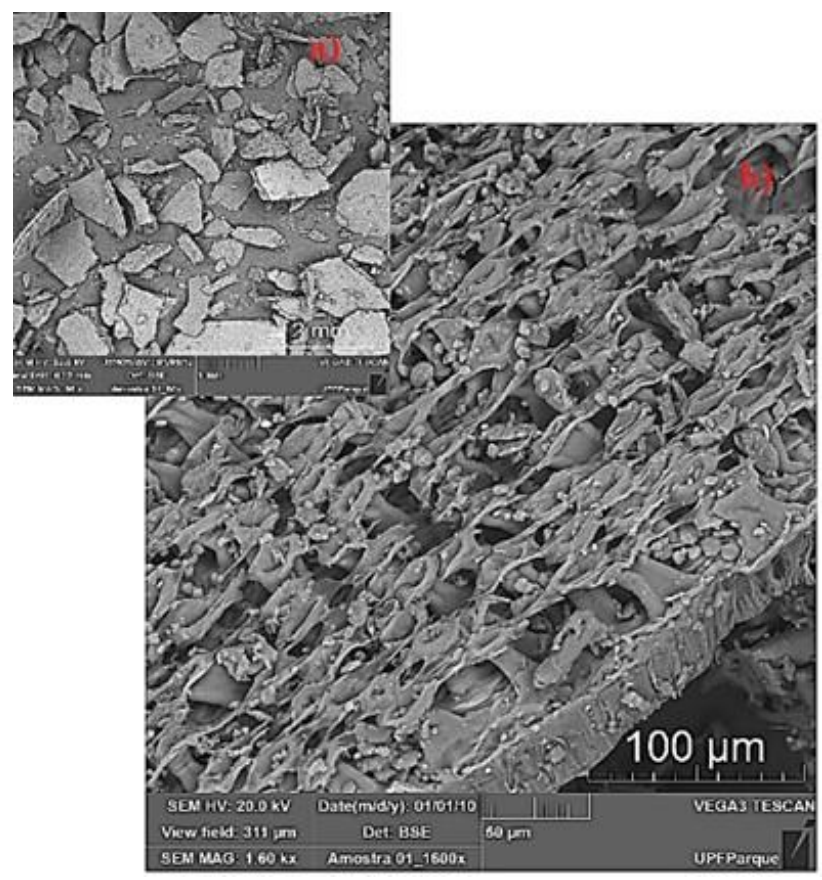

Figure 1: Scanning electron microscopy of soybean hull in natura with increases of (a) 80 and (b) 1600 times

To determine the vibration frequencies of possible functional groups, present in the soybean hull, the infrared spectroscopy technique was applied. Each group has a characteristic frequency, so it is possible to propose through this analysis the presence of the groups that are part of the soybean hull, characteristics of which directly influence the adsorption process. Figure 2 shows the FTIR spectrum of the soybean hull.

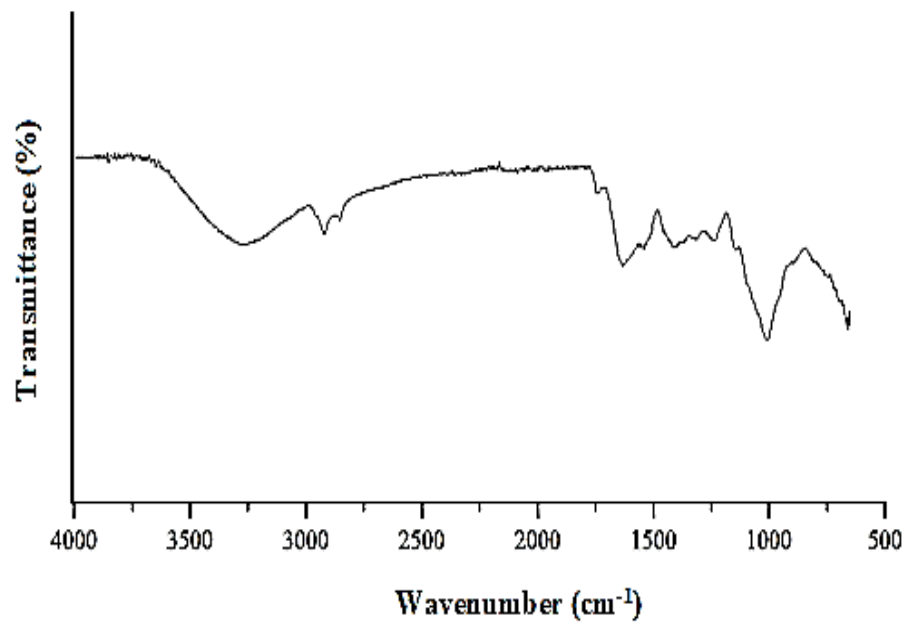

Figure 2: Fourier transform infrared (FTIR) spectra of soybean hull

Figure 2 presents a set of characteristic bands of lignocellulosic substances, as expected. According to ALEMDAR and SAIN [13], the wideband located at $3412 \mathrm{~cm}^{-1}$ is attributed to the symmetric stretching vibrations of $\mathrm{OH}$ groups, indicating both the presence of cellulose hydroxyl groups and structural or absorbed water. The bands at $2925 \mathrm{~cm}^{-1}$ and $2855 \mathrm{~cm}^{-1}$ are due to $-\mathrm{C}-\mathrm{H}$ stretching vibrations. Peaks of $1061 \mathrm{~cm}^{-1}$ and $794 \mathrm{~cm}^{-1}$ are related to the $\mathrm{C}-\mathrm{O}-\mathrm{C}$ elongation and the $\mathrm{C}-\mathrm{H}$ rocking vibrations of cellulose. Some peaks at $1744 \mathrm{~cm}^{-1}, 1647 \mathrm{~cm}^{-1}$, and $1417 \mathrm{~cm}^{-1}$ are associated with the -C-O vibrations of the carboxyl group. A similar molecular structure was also found by WEI et al. [12] and ALEMDAR and SAIN [13]. 


\subsection{Adsorption kinetics and isotherms}

The adsorption kinetics is a measure of control of the adsorbate diffusion in the pores under pressure, concentration, $\mathrm{pH}$, and constant flow, where expressed in a curve or line, describes the retention rate of a solute in an aqueous environment for a solid interface, aiming at the equilibrium. During adsorption, two processes occur, physisorption and chemisorption. Physisorption is the result of weak attraction forces while chemisorption involves the formation of strong bonds between the solute and the adsorbate that involves the transfer of electrons [14, 15]. Adsorption kinetics are shown in Figure 3. In this test, after 120 min the equilibrium was observed, and about $88 \%$ of the $5 \mathrm{G}$ blue reactive dye was removed from the aqueous solution. The kinetic parameters of the proposed models (Equations 2 and 3) are presented in Table 2.

From the analysis of the parameters of the kinetic models under study (Table 2), it was noted that both can be used to describe the adsorption kinetics of the present study with $\mathrm{R}^{2}=0.94$ and 0.99 for the pseudofirst and pseudo-second order models, respectively. However, the pseudo-second order model presented a better adjustment to the experimental data, as well as a higher value for solute adsorbed in the equilibrium, which in this case was $17.20 \mathrm{mg} \mathrm{g}^{-1}$. A similar result was observed in MÓDENES et al. [16] using soybean hulls on the removal of BF-4B dye, which had a better adjustment with the pseudo-second order model with $\mathrm{R}^{2}=0.97$, however, its maximum adsorption in the equilibrium remained at $8.895 \mathrm{mg} \mathrm{g}^{-1}$. The pseudo-second order model indicates that the adsorption rate of the solute is proportional to the free sites of the adsorbent [15].

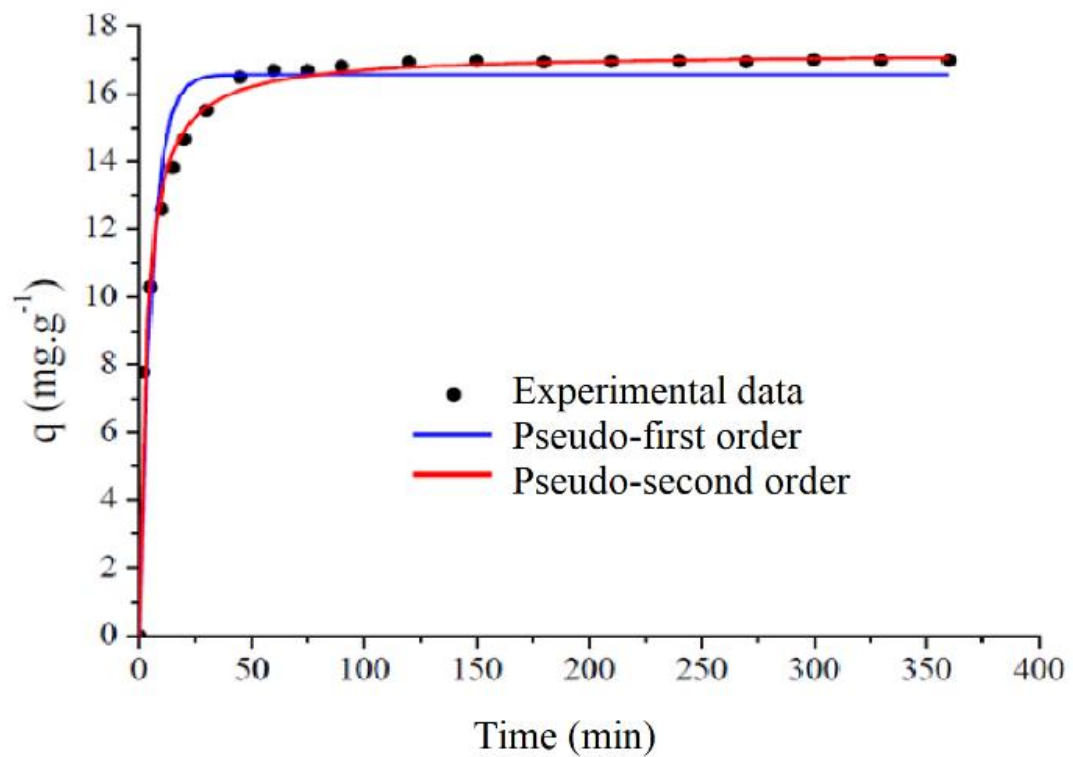

Figure 3: Kinetic profile and mathematical modeling of adsorption of $5 \mathrm{G}$ blue reactive dye by soybean hulls $\left(40^{\circ} \mathrm{C}, 90\right.$ $\mathrm{rpm}$ and $\mathrm{pH}$ 2)

Table 2: Parameters of kinetic models for $5 \mathrm{G}$ blue reactive dye adsorption by soybean hulls $\left(40{ }^{\circ} \mathrm{C}, 90 \mathrm{rpm}\right.$ and $\left.\mathrm{pH} 2\right)$

\begin{tabular}{l|c|c}
\hline \multirow{2}{*}{ MODELS } & \multicolumn{2}{|c}{ PARAMETERS } \\
\hline \multirow{3}{*}{ Pseudo-first order } & $\mathrm{q}_{\mathrm{t}}\left(\mathrm{mg} \mathrm{g}^{-1}\right)$ & 16.56 \\
\cline { 2 - 3 } & $\mathrm{k}_{1}\left(\mathrm{~min}^{-1}\right)$ & 0.181 \\
\cline { 2 - 3 } & $\mathrm{R}^{2}$ & 0.9498 \\
\hline \multirow{3}{*}{ Pseudo-second order } & $\mathrm{q}_{\mathrm{t}}\left(\mathrm{mg} \mathrm{g}^{-1}\right)$ & 17.20 \\
\cline { 2 - 3 } & $\mathrm{k}_{2}\left(\mathrm{~g} \mathrm{mg} \mathrm{min}^{-1}\right)$ & 0.018 \\
\cline { 2 - 3 } & $\mathrm{R}^{2}$ & 0.9937 \\
\hline
\end{tabular}

Another very useful tool in the compression of the process mechanisms is the isotherm, which reveal the potential for adsorption of the biosorbent by the solute in the face of the conditions of the experimental medium in which it was submitted, moreover, these isotherms are based on mathematical models, simplify- 
ing the description of the adsorption and desorption data of the system, through empirical variables and simple equations [17].

It can also be said that isotherms are mechanisms of understanding adsorption and can quantitatively assess the distribution of solutes of interest in equilibrium between solid and liquid phases [18]. The adsorption isotherm of the 5G blue reactive dye using soybean hulls are shown in Figure 4. It is observed that the isotherm has a concave characteristic, indicating that the adsorption process is favorable, providing high dye removal capacity type L2 or $\mathrm{H} 2$, according to the classification suggested by GILES et al. [19]. This type of isotherm further suggests that the adsorbent has several finite sites, which when filled with no additional adsorption can occur, leading to the formation of a plateau. The maximum capacity $\left(\mathrm{q}_{\mathrm{eq}}\right)$ obtained from the experimental data was $53.33 \mathrm{mg} \mathrm{g}^{-1}$.

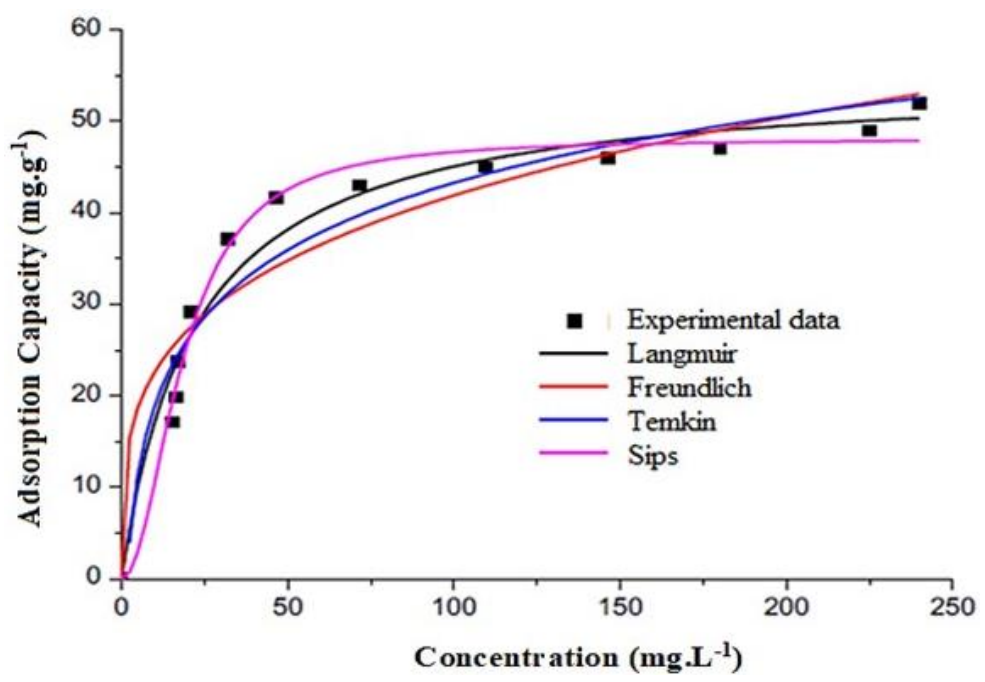

Figure 4: Equilibrium isotherm and mathematical modeling of $5 \mathrm{G}$ blue reactive dye adsorption by soybean hulls $\left(40^{\circ} \mathrm{C}\right.$, $90 \mathrm{rpm}$, and $\mathrm{pH} 2$ ).

Table 3 shows the adjustment of the equilibrium data to the adsorption isothermal models represented by Equations 4 to 7 . The coefficients of determination $\left(R^{2}\right)$ of Langmuir, Freundlich, Redlich-Peterson, and Sips models equal or are greater than 0.90 showing that these models are suitable for representing the experimental data of adsorption of $5 \mathrm{G}$ blue reactive dye. However, despite presenting a good $\mathrm{R}^{2}$, the Sips model is what is closest to the ideal, because its curve accompanies the data of the experiment, designing an $\mathrm{R}^{2}$ of excellent value, as represented in Figure 4. Besides, the maximum adsorption capacity would be $48.13 \mathrm{mg} \mathrm{g}^{-1}$ according to the model. A similar fit was reported by HOLANDA et al. [20] which removed the Remazol turquoise textile dye using Eichhornia crassipes as adsorbent, where the best fit model was Sips with $\mathrm{R}^{2}=$ 0.99 . 
Table 3: Equilibrium model parameters for adsorption of $5 \mathrm{G}$ blue reactive dye adsorption by soybean hulls $\left(40^{\circ} \mathrm{C}, 90\right.$ rpm and $\mathrm{pH}$ 2)

\begin{tabular}{|c|c|c|}
\hline MODELS & PARAMETERS & $250 \mathrm{MG} \mathrm{L}^{-1}$ \\
\hline \multirow{3}{*}{ Langmuir } & $\mathrm{q}_{\max }\left(\mathrm{mg} \mathrm{g}^{-1}\right)$ & 54.97535 \\
\hline & $\mathrm{k}_{\mathrm{L}}\left(\mathrm{L} \mathrm{mg}^{-1}\right)$ & 0.0064 \\
\hline & $\mathrm{R}^{2}$ & 0.96229 \\
\hline \multirow{3}{*}{ Freundlich } & $\mathrm{k}\left(\mathrm{L} \mathrm{g}^{-1}\right)$ & 12.18967 \\
\hline & $\mathrm{N}$ & 3.72887 \\
\hline & $\mathrm{R}^{2}$ & 0.90663 \\
\hline \multirow{3}{*}{ Temkin } & $\mathrm{b}\left(\mathrm{kJ} \mathrm{mol}^{-1}\right)$ & 10.58418 \\
\hline & $\mathrm{k}_{\mathrm{t}}\left(\mathrm{L} \mathrm{mg}^{-1}\right)$ & 0.59718 \\
\hline & $\mathrm{R}^{2}$ & 0.93636 \\
\hline \multirow{4}{*}{ Sips } & $\mathrm{q}_{\mathrm{s}}\left(\mathrm{mg} \mathrm{g}^{-1}\right)$ & 48.13462 \\
\hline & $\mathrm{k}_{s}\left(\mathrm{~L} \mathrm{mg}^{-1}\right)$ & 0.05395 \\
\hline & $b_{s}$ & 2.05158 \\
\hline & $\mathrm{R}^{2}$ & 0.99551 \\
\hline
\end{tabular}

Sips model is characterized by being a combination of Langmuir and Freundlich models predicting the adsorption in heterogeneous systems and circumventing the limitation of the rising adsorbate concentration associated with the Freundlich isotherm. High concentrations of adsorbate presuppose Langmuir-like behavior that shows single-layer adsorption capacity, while low concentrations presume the similarity of isotherm of Freundlich, which forms more than one layer of adsorbate on the adsorbent [21]. Thus, the Sips model was chosen to represent the equilibrium data of this work.

\section{CONCLUSIONS}

Through the morphological characterization of the biosorbent, it was possible to evidence superficial pores in practically all their extension, a characteristic that directly influences the adsorption process. The analysis of FTIR showed, as expected, the presence of functional groups characteristic of lignocellulosic substances.

Besides, the results obtained in the kinetic and equilibrium essays in the studied conditions show that the adsorption equilibrium was obtained in about $120 \mathrm{~min}$, with the removal of $88 \%$ of the dye, with the pseudo-second order model and Sips, the mathematical models that best represent the kinetic and equilibrium data, respectively. The maximum adsorption capacities calculated experimentally and predicted by the Sips model were $53.33 \mathrm{mg} \mathrm{g}^{-1}$ and $48.13 \mathrm{mg} \mathrm{g}^{-1}$, respectively. In general, the biosorbent studied was effective to remove the reactive dye.

\section{ACKNOWLEDGMENTS}

The authors would like to acknowledge the Coordination for the Improvement of Higher Education Personnel (CAPES) - Finance Code 001 and the Research Support Foundation of Mato Grosso State (FAPEMAT).

\section{BIBLIOGRAPHY}

[1] SOUZA, S.M.A.G.U., PERUZZO, L.C., DE SOUZA, A.A.U., "Numerical study of the adsorption of dyes from textile effluents", Applied Mathematical Modelling, v. 32, n. 9, pp. 1711-1718, 2008.

[2] HOSSAIN, L., SARKER, S.K., KHAN, M.S., "Evaluation of present and future wastewater impacts of textile dyeing industries in Bangladesh", Environmental Development, v. 26, pp. 23-33, 2018.

[3] RIGUETO, C.V.T.; PICCIN, J.S.; DETTMER, A., et al., "Water hyacinth (Eichhornia crassipes) roots, an amazon natural waste, as an alternative biosorbent to uptake a reactive textile dye from aqueous solutions”, Ecological Engineering, v. 150, pp. 105817, 2020. 
[4] RIGUETO, C.V.T.; NAZARI, M.T.; DE SOUZA, C.F., et al., "Alternative techniques for caffeine removal from wastewater: An overview of opportunities and challenges". Journal of Water Process Engineering, v. 35, pp. 101231, 2020.

[5] JIA, L.I., ENZAN, C.H.E.N., HAIJIA, S.U., et al., "Biosorption of $\mathrm{Pb}^{2+}$ with modified soybean hulls as absorbent”, Chinese Journal of Chemical Engineering, v. 19, n. 2, pp. 334-339, 2011.

[6] EMBRAPA, Soja em números (Safra 2018/19), https://www.embrapa.br/soja/cultivos/soja1/dadoseconomicos. Accessed in December 2019.

[7] VEAZEY, M.V., "Researchers find new use for soybean hulls". Materials Performance, v. 40, n. 6, pp. 45, 2001.

[8] DEFRAIN, J., SHIRLEY, J., BEHNKE, K., et al., "Development and evaluation of a pelleted feedstuff containing condensed corn steep liquor and raw soybean hulls for dairy cattle diets". Animal Feed Science and Technology, v. 107, n. 1-4, pp. 75-86, 2003.

[9] RIGUETO, C.V.T., FONSECA, F.C.A., ZANELLA, B.B., et al., "Adsorption study with NaOH chemically treated soybean hull for textile dye removal". Revista Ibero-Americana de Ciências Ambientais, v. 10, n. 5, pp. 161-168, 2019.

[10] PICCIN, J.S., GUTERRES, M., SALAU, N.P.G., et al., "Mass transfer models for the adsorption of Acid Red 357 and Acid Black 210 by tannery solid wastes". Adsorption Science \& Technology, v. 35, n. 3-4, pp. 300-316, 2017.

[11] ARAMI, M., LIMAEE, N.Y., MAHMOODI, N.M., et al., "Equilibrium and kinetics studies for the adsorption of direct and acid dyes from aqueous solution by soy meal hull". Journal of Hazardous Materials, v. 135, n. 1-3, pp. 171-179, 2006.

[12] WEI, X., LI, H.R., WANG, L., et al., "Soybean hulls residue adsorbent for rapid removal of lead ions". Pure and Applied Chemistry, v. 86, n. 5, pp. 711-720, 2014.

[13] ALEMDAR, A., SAIN, M., "Isolation and characterization of nanofibers from agricultural residues Wheat straw and soy hulls". Bioresource Technology, v. 99, n. 6, pp. 1664-1671, 2008.

[14] SAHA, D., GRAPPE, H.A., “Adsorption properties of activated carbon fibers". In: Chen, J.Y. (ed), Activated Carbon Fiber and Textiles, chapter 5, Woodhead Publishing, pp. 143-165, 2017.

[15] KAJJUMBA, G.W., EMIK, S., ÖNGEN, A., et al., "Modeling of adsorption kinetic processes - errors, theory and application”. In: Edebali, S. (ed), Advanced sorption process applications, chapter 10, IntechOpen, 2018.

[16] MÓDENES, A.N., HINTERHOLZ, C.L., NEVES, C.V., et al., "A new alternative to use soybean hulls on the adsorptive removal of aqueous dyestuff”. Bioresource Technology Reports, v. 6, pp. 175-182, 2019.

[17] CHAKRABORTY, S., DE, S., DASGUPTA, S., et al., "Adsorption study for the removal of a basic dye: experimental and modeling". Chemosphere, v. 58, n. 8, pp. 1079-1086, 2005.

[18] PAL, P., "Physicochemical Treatment Technology". In: Pal, P (ed), Industrial Water Treatment Process Technology, 1 ed., chapter 4, Elsevier, Cambridge, pp. 145-171, 2017.

[19] GILES, C.H., MACEWAN, T.H., NAKHWA, S.N., et al., "A system of classification of solution adsorption isotherms, and its use in diagnosis of adsorption mechanisms and measurement of specific surface areas of solids". Journal of the Chemical Society, v. 2, pp. 3973-3993, 1960.

[20] HOLANDA, C.A., SOUZA, J.L., DOS SANTOS, C.C., et al., "Remoção do corante têxtil turquesa de remazol empregando aguapé (Eichhornia crassipes) como adsorvente". Orbital: The Electronic Journal of Chemistry, v. 7, n. 2, pp. 141-154, 2015.

[21] TZABAR, N., TER BRAKE, H.J.M., "Adsorption isotherms and Sips models of nitrogen, methane, ethane, and propane on commercial activated carbons and polyvinylidene chloride". Adsorption, v. 22, n. 7, pp. 901-914, 2016.

ORCID

Cesar Vinicius Toniciolli Rigueto

Samara Correia Harala

Marieli Rosseto https://orcid.org/0000-0003-2778-5170

https://orcid.org/0000-0003-0554-6654

https://orcid.org/0000-0003-4741-2224 
Bruna Elisangela Pessini Ostwald Lillian Ávila Massuda Mateus Torres Nazari

Aline Dettmer

Raquel Aparecida Loss

Claudineia Aparecida Queli Geraldi https://orcid.org/0000-0003-2681-4582

https://orcid.org/0000-0001-5039-9011

http://orcid.org/0000-0002-2548-9047

https://orcid.org/0000-0002-6578-9159

https://orcid.org/0000-0002-6022-7552

https://orcid.org/0000-0001-5255-9752 